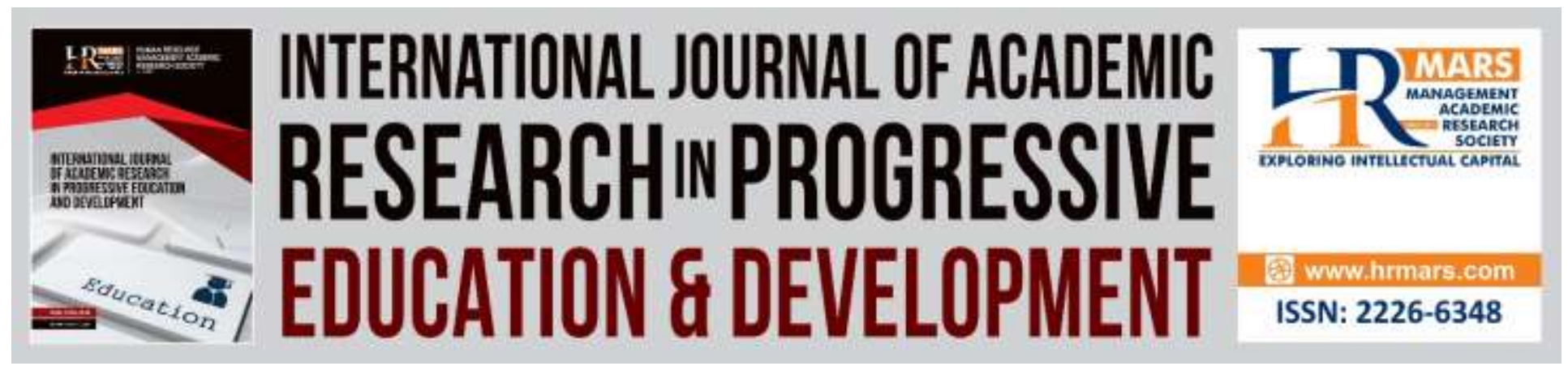

\title{
The Influence of the Role Conflict and Role Ambiguity towards Counseling Competency in Supervision among Trainee Counselors in Malaysia
}

Suhaili Arifin, Sidek Mohd Noah, Wan Marzuki Wan Jaafar, Noor Syamilah Zakaria

To Link this Article: http://dx.doi.org/10.6007/IJARPED/v8-i4/6437

DOI: 10.6007/IJARPED/v8-i4/6437

Received: 01 August 2019, Revised: 20 August 2019, Accepted: 04 September 2019

Published Online: 18 September, 2019

In-Text Citation: (Arifin, Noah, Jaafar, \& Zakaria, 2019)

To Cite this Article: Arifin, S., Noah, S. M., Jaafar, W. M. W., \& Zakaria, N. S. (2019). The Influence of the Role Conflict and Role Ambiguity towards Counseling Competency in Supervision among Trainee Counselors in Malaysia. International Journal of Academic Research in Progressive Education and Development, 8(4), 7790.

Copyright: (C) 2019 The Author(s)

Published by Human Resource Management Academic Research Society (www.hrmars.com)

This article is published under the Creative Commons Attribution (CC BY 4.0) license. Anyone may reproduce, distribute, translate and create derivative works of this article (for both commercial and non-commercial purposes), subject to full attribution to the original publication and authors. The full terms of this license may be seen

at: http://creativecommons.org/licences/by/4.0/legalcode

\section{Vol. 8(4) 2019, Pg. 77 - 90}

http://hrmars.com/index.php/pages/detail/IJARPED

JOURNAL HOMEPAGE

Full Terms \& Conditions of access and use can be found at http://hrmars.com/index.php/pages/detail/publication-ethics 


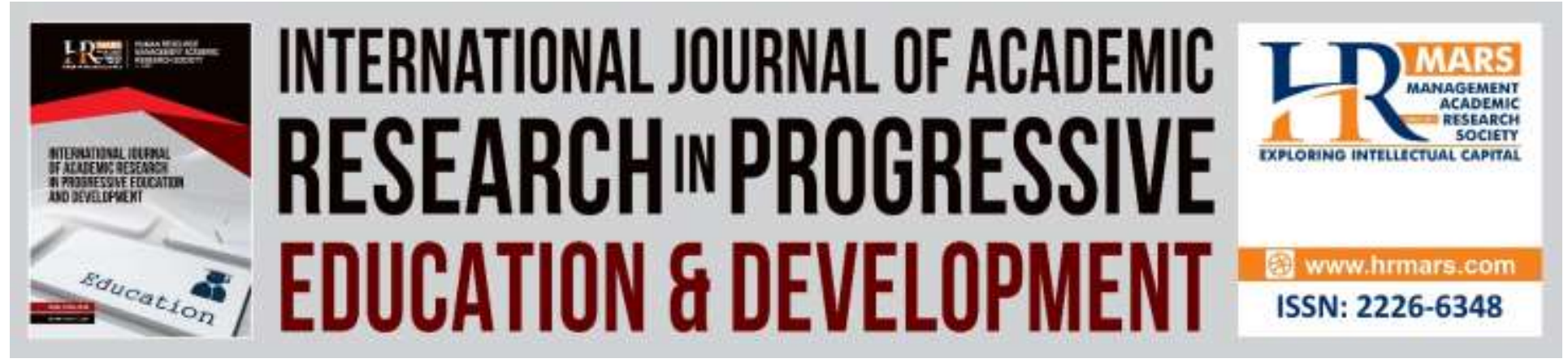

\title{
The Influence of the Role Conflict and Role Ambiguity towards Counseling Competency in Supervision among Trainee Counselors in Malaysia
}

\author{
Suhaili Arifin, Sidek Mohd Noah, Wan Marzuki Wan Jaafar, Noor \\ Syamilah Zakaria
}

Department of Counselor Education and Counseling Psychology, Faculty of Educational Studies, University of Putra Malaysia, Malaysia

\begin{abstract}
This study was a correlational research aiming to investigate the relationship between role conflict and role ambiguity, and counseling competencies among trainee counselors in the supervision process. Next, this study also seeks to examine the influence of both factors towards the study's dependent variables. For the respondents, 217 trainee counselors and 67 supervisor lecturers from nine public universities in Malaysia were involved. Two instruments were used to measure the variables in this study namely The Role Conflict and Role Ambiguity Inventory (RCRAI) and Counseling Competencies Scale (CCS). RCRAI was administered to measure the role conflict and role ambiguity among trainee counselors, while CCS functions to assist the supervisors in evaluating the counselors' competencies. Based on the study findings, there was a significant correlation between role conflict and role ambiguity with counseling competencies $r=.170, p<.05$; and $r=-.542, p<.05$, respectively. For the multiple regression analyses, it is reported that the model was a significant predictor of counseling competencies, $R^{2}=2.95, F(2$, $201)=41.994, p<.000$. The model also indicates that only role ambiguity had contributed significantly $(\beta=-.434, p<.05)$, while role conflict had not $(\beta=-.046, p>.05)$. All these findings provide future research directions to improve the level of competencies among the trainee counselor in the supervision process. For this purpose, the study implications on counselor competencies in the supervision as well as on the relationship between both the supervisor and trainee are discussed.
\end{abstract}

Keywords: Role Conflict, Role Ambiguity, Supervision, Counseling Competency, Trainee Counselors

\section{Introduction}

The supervision process is applied in various professions such as clinical psychology, nursing, school psychology and teaching (Dollarhide \& Miller, 2006). The demand for supervision is not exempted in the counseling profession as a professional field. In general, Loganbill, Hardy, 
\& Delworth (1982) define supervision as "intensive, interpersonally one-to-one relationship in which one person is designed to facilitate the development of therapeutic competence in the other person" (pg. 14). Bernard \& Goodyear (2009) define supervision as an intervention given to senior members to junior members in the same profession, comprising of the aspect of evaluation carried out within a particular duration. The author adds that there are three main aims of supervision which is increasing the professional function of new members, monitoring professional service quality offered to clients, and as a gatekeeping for those interested in this profession. Supervision is also a basic component in the development of identity of professional trainee counselors who will serve in this profession (West, 2004), by increasing their sharpness of skills, conceptualizing and delivering service effectively to the clients (Bornsheuer-Boswell, Polonyi, \& Watts, 2013). Meanwhile, Ladany \& Bradley (2010) raise three main functions of counseling supervision: (1) helping the counselor obtain professional growth and personnel characteristics; (2) increase a sense of responsibility on giving service and counseling program; and (3) increase the counselor's competency level. Many opinions have been raised by scholars aiming to elaborate on all the aspects encompassed in the counseling supervision in detail. It can be concluded that counseling supervision is a form of examination towards counselor activities by the supervisor, involving certain interaction process, and aiming to empower the counselor's competency level to a professional level.

The aspect of professional competency has long been gaining attention in applied psychology (Ridley, Mollen, \& Kelly, 2011), and this includes counseling education. A counselor who provides service without having any basic competency is feared to not only fail to give benefit, but also he or she will bring a negative implication towards the clients' psychology as a whole. This cannot be seen as trivial because it can ruin the image of the profession and affect all the counselors in service. To avoid this, the counseling profession has given an emphasis on all counselors including trainee counselors so that they can uphold this profession by protecting and taking care of the welfare of their existing clients (Foster \& McAdams, 2009). One of them is by mastering the competency skills well. Thus, all professional counselors will need some training to access the counseling competency so that they can evaluate their own competency level, their peers' competency level and also the trainee counselors' competency level (Swank, 2014). In Malaysia, there is a Counselor Code of Ethics dictated in the national law by the Board of Counselors (Malaysia) (2011). This ethic code is a guideline related to the ethical responsibility and behavior as a counselor. One of the main highlights of the ethics code is that it requires every counselor to have competency before they carry out their duties as a counselor. Meanwhile, the task carried out is confined under the scope of competency that they have mastered only. This is clear under Section (C): Professional Responsibility; Section (C.2) Professional Competency, Sub-section (C.2.a) whereby: "Counselor must conduct their professional work only in the scope of competency based on education, training, experience supervised, professional accreditation also relevant professional experiences. A counselor must gain knowledge, develop personal awareness, sensitivity and skills related to his or her services for various clients" (pg. 16). The next code outlines the responsibilities of educator-counselors towards the significance of the competency in supervision in Section (F): Supervision, Training and Teaching under Sub Section (F.9.a). Meanwhile, the ethics code under sub-section (F.8.b) and 
(F.9.b) explains the responsibility of trainee counselors and educator counselors to raise the awareness about the incapability and limitations of trainee counselors towards counseling competency. Both the codes demand for educator counselors to assist trainee counselors in obtaining professional service to achieve the supposed counseling competency level, or to terminate it if they are deemed incapable so much so that it is detrimental to the client. Based on the ethics code, competency is shown to serve as a guarantee to a counseling service that has high quality and is safe to the clients and to the profession itself.

Thus, the topic of counseling competence has become more and more significant in recent years, along with a growing demand for quality counseling, increased credentialing efforts, and a focus on the professionalization of counseling (Pelling, 2009). Based on the literature review, scholars have put forth several factors that affect the competency in trainee counselors in supervision. One of the factors is related to the complexity of role. Citing Nelson \& Friedlander (2001), trainee counselors need to be prepared in the supervision to face new and more complicated tasks other than the fact that they have to carry different roles. When supervising, supervisors' main aim is to address how trainee counselors under their supervision to play the roles. This is because a competent counselor will of course be able to carry out his or her duty and responsibility well and professionally. According to Olk \& Friedlander (1992), the difficult role faced by trainee counselors in supervision normally comprises of the role conflict and ambiguity of role. Role conflict happens when there is a clash of role in the supervision that needs to be played by a trainee counselor at any one time. The writer asserts that role conflict can also occur when the supervisor's instructions are not consistent with the trainee counselor's own evaluation or views. He adds that, role conflict tends to involve experiences in which expectations associated with the role of student oppose those associated with the role of the counselor and colleague. In the role of the student, the trainee is expected to follow the supervisor's directives and recommendations, but in the roles of the counselor and colleague, the trainee is expected to demonstrate a capacity for autonomous decision making. In turn, the ambiguity of role happens when a trainee counselor is not clear about the expectation in the supervision, the kind of role expected, and how they will be evaluated (Olk \& Friedlander, 1992). According to Jahn \& Adcock (2017), ambiguity stems from the moment when the trainee counselor is trying to be a student, a trainee counselor, and a new, professional and competent counselor at the same time. Every role has particular expectations on the behavior of the trainee counselor in supervision (Olk \& Friedlander, 1992).

\section{Problem Statement}

Competency is a significant aspect that has been emphasized on trainee counselors in the counseling supervision process in Counselor Ethics Code (Board of Counselors (Malaysia), 2011); and Counselor Training Standard and Qualification (Board of Counselors (Malaysia), 2015); as well as a determinant to the effectiveness of counseling and to a therapeutic outcome to the client (Ridley et al., 2011). To date, only a small percentage of the variables have been addressed in the literature on supervision, have rarely been studied both systematically and programmatically (Ladany \& Malouf, 2010). These variables including issues of role conflict and role ambiguity related to trainee counselor's competency. Nonetheless, both of the components 
can hinder the growth and development of the trainee counselor being supervised. Thus, Kulp (2012) proposes that the issue of the complexity of role of trainee counselor in supervision should be emphasize and resolve because the impact can thwart the trainee counselor's potential in the supervision and has the potential to adversely affect the client. However, previous literature has shown that the number of empirical studies related to role conflict and ambiguity of role on the competency in supervision is very limited particularly in Malaysia context. Issues like this cannot be taken lightly because they can affect the function of supervision in boosting the development of trainee counselor competency. Thus, a study has to be done objectively and practically to investigate the extent to which the difficulty of role has an association with, and contributes to, the counseling competency among trainee counselors in the public universities all over Malaysia.

The objectives of this study are as follows:

a. To study the relationship between role conflict and counseling competency among trainee counselors

b. To study the relationship between the role ambiguity and counseling competency among trainee counselors

c. To study the influence of role conflict and role ambiguity towards counseling competency among trainee counselors

The hypotheses of this study are as follows:

- $\mathrm{H}_{01}$ There is no significant relationship between role conflict and counseling competency among trainee counselors

- $\mathrm{H}_{\mathrm{o} 2}$ There is no significant relationship between role ambiguity and counseling competency among trainee counselors

- $\mathrm{H}_{\mathrm{o3}} \quad$ There is no influence of role conflict and role ambiguity towards the counseling competency among trainee counselors

\section{Research Method}

\section{Research Design}

This study is a quantitative study that uses the correlational design to measure the relationship and influence between the independent variables (role conflict and role ambiguity); with the dependent variable (counseling competency of the trainee counselors). According to Bordens \& Abbott (2014), the correlation design is appropriate for studies that intend to see the association between two or more variables to determine the direction, magnitude, also the form of relationship that exist. Other than this, the correlation design also serves to predict the value of the dependent variable when the value of the independent variable is known (Babbie, 2014).

\section{Subject and Selection}

The study respondents comprise of two groups namely the trainee counselors $n=217$ at the first degree level of their counseling program; and counseling lecturers $n=67$ who are the trainee counselors' supervisors that have been chosen as the respondents in this study. The selection of respondents is through the stratified random sampling technique, as the number of trainee counselors in this study differs from one university to another. The stratified random sampling technique works well for imbalanced population on certain category, level or group (Creswell, 
2012), and it is a good choice to retain the representative level other than reducing the sampling error for this type of population (Babbie, 2014). All the respondents were selected from nine public universities acknowledged by Board of Counselors Malaysia and Malaysian Qualification Accreditation all across Malaysia. The public universities are Universiti Putra Malaysia (UPM), Universiti Pendidikan Sultan Idris (UPSI), Universiti Malaya (UM), Universiti Utara Malaysia (UUM), Universiti Malaysia Sabah (UMS), Universiti Malaysia Sarawak (UNIMAS), Universiti Malaysia Terengganu (UMT), Universiti Sains Islam Malaysia (USIM), and Universiti Islam Antarabangsa Malaysia (UIAM).

\section{Instrumentation}

The instrumentation that was used in this study consists of three sections. Section I contains the background of the respondents, while section II contains the Role Conflict and Role Ambiguity Inventory (RCRAl; Olk \& Friedlander, 1992) to measure the role conflict and role ambiguity variables. The last instrument in section III contains the Counseling Competency Scale (CCS; Lambie, Mullen, Swank, Blount, 2018) to measure trainee counselors' competencies. For RCRAI, there are two sub-scales namely role conflict and role ambiguity; whereas CCS also contains two sub-scales which is counseling skills and therapeutic condition, and counseling dispositions and behaviors. Both instruments are in English and they were translated into Malay Language and adapted to the local culture using the back-to-back translation procedure as proposed by Brislin, Lonner \& Thondiqke (1973). After the translation, the instrument was sent to four expert evaluators to check the content validity. All the comments and the suggestions from the evaluators on the instrument were considered for improvement. The validity value obtained in this study is high showing that all the item content for every instrument is valid or represents the construct that is to be measured.

Table 1: Content validity value for every sub-scale

\begin{tabular}{|c|l|c|c|c|}
\hline Instrument & Sub scales & $\begin{array}{c}\text { Maximum } \\
\text { value }\end{array}$ & $\begin{array}{c}\text { Minimum } \\
\text { value }\end{array}$ & $\begin{array}{c}\text { Overall } \\
\text { value }\end{array}$ \\
\hline \multirow{3}{*}{ RCRAI } & Roles conflict & .95 & .78 & .90 \\
\cline { 2 - 5 } & Roles ambiguity & .95 & .80 & .87 \\
\hline \multirow{3}{*}{ CSC } & Counseling skills and therapeutic condition & .95 & .80 & .91 \\
\cline { 2 - 5 } & Counseling dispositions and behaviors & .95 & .88 & .94 \\
\hline
\end{tabular}

For the reliability value, a pilot study involving 30 trainee counselors and 8 supervisor lecturers from UPSI was carried out. Based on the analysis, the alpha croanbach value $(\alpha)$ for RCRAI and CCS exceeds $\alpha>.60$, similar to the actual study, proving that both instruments adopted have a good reliability value. Table 2 di below displays reliability value in both the pilot study and the actual study. 
INTERNATIONAL JOURNAL OF ACADEMIC RESEARCH IN PROGRESSIVE EDUCATION AND DEVELOPMENT

Vol. 8, No. 4, 2019, E-ISSN: 2226-6348 @ 2019 HRMARS

Table 2: Reliability Value $(\alpha)$

\begin{tabular}{|c|c|c|c|}
\hline \multirow{2}{*}{ Instrument } & Sub-scale & $\begin{array}{c}\text { Pilot study } \\
(\mathrm{n}=30)\end{array}$ & $\begin{array}{c}\text { Actual study } \\
(\mathrm{n}=204)\end{array}$ \\
\hline \multirow{2}{*}{ RCRAI } & Roles Ambiguity & .956 & .958 \\
\cline { 2 - 4 } & Roles Conflict & .779 & .857 \\
\hline CSC & Overall sub-scales & .955 & .955 \\
\hline
\end{tabular}

\section{Study Procedure}

Researcher had requested for the permission to conduct her research to all Assistants of the Academic Deputy Chancellors of all the universities involved. After the permission is granted, full details of all the trainee counselors and educator supervisors were provided to the researcher by the universities involved. The information was perfectly sorted and arranged to ensure that the name of the student and the name of the supervisor are corresponding with one another before they were chosen using the stratified random sampling technique. Every respondent was contacted beforehand to get their agreement and cooperation before the questionnaire was distributed. They were also allowed to withdraw if they did not want to take part or give feedback in this study. The data collection process started at the end of the second semester because normally during this time of year, trainee counselors will almost finish their internship training and have been supervised by their respective supervisors.

\section{Research Findings}

Respondents' Demographic Information

Table 3 shows the frequency of the trainee counselors and the supervisors according to their respective universities. For trainee counselor, the highest frequency is from UMT, which is $21.6 \%(n=44)$, followed by USIM and UMS with the same frequency $14.7 \%(n=30)$ respectively. Next, UNIMAS is $11.8 \% \quad(n=24)$, followed by UPSI which is $11.3 \%(n=23)$, and UUM $8.8 \%(n=18)$. Meanwhile UM shares the same frequency percentage with UIAM which is $5.9 \%(n=12)$, and UPM shows the lowest frequency which is $5.4 \%(n=11)$. Meanwhile for the supervising lecturer, the majority is from UPSI, $17.7 \%(n=11)$ and this is followed by UMT $16.1 \%(n=10)$. The frequency for UNIMAS is the same with UUM totalling $12.9 \%(n=8)$, and the frequency of USIM is the same with UM, 9.7\% $(n=6)$, and UPM has the same frequency with UIAM which is $6.5 \%(n=4)$ respectively. Last but not least, the frequency of the educator supervisors from UMS is $8.1 \%$ $(n=5)$. 
INTERNATIONAL JOURNAL OF ACADEMIC RESEARCH IN PROGRESSIVE EDUCATION AND DEVELOPMENT

Vol. 8, No. 4, 2019, E-ISSN: 2226-6348 @ 2019 HRMARS

Table 3: Frequency of trainee counselor and supervisor lecturer according to university

\begin{tabular}{|c|c|c|c|c|}
\hline University & Trainee counselor & Percentage (\%) & Supervisor lecturer & Percentage (\%) \\
\hline UPM & 11 & 5.4 & 4 & 6.5 \\
\hline UPSI & 23 & 11.3 & 11 & 17.7 \\
\hline UM & 12 & 5.9 & 6 & 9.7 \\
\hline UUM & 18 & 8.8 & 8 & 12.9 \\
\hline UMS & 30 & 14.7 & 5 & 8.1 \\
\hline UNIMAS & 24 & 11.8 & 8 & 12.9 \\
\hline UMT & 44 & 21.6 & 10 & 16.1 \\
\hline USIM & 30 & 14.7 & 6 & 9.7 \\
\hline UIAM & 12 & $100 \%$ & 4 & 6.5 \\
\hline Total & 204 & 62 & $100 \%$ \\
\hline
\end{tabular}

Table 4 displays the frequency of the respondents by gender. The majority of the respondents comprise of female totalling $82.4 \%(n=168)$ for trainee counselors, and $67.7 \%(n=42)$ for the supervisors. Male respondents constituted $17.6 \%(n=36)$ for trainee counselors, and $32.3 \%(n=20)$ for the supervisors.

Table 4: Frequency of trainee counselor and supervisor lecturer according to gender

\begin{tabular}{|c|c|c|c|c|}
\hline Gender & Trainee counselor & Percentage (\%) & Supervisor lecturer & Percentage (\%) \\
\hline Male & 36 & 17.6 & 20 & 32.3 \\
\hline Female & 168 & 82.4 & 42 & 67.7 \\
\hline Total & 204 & $100 \%$ & 62 & $100 \%$ \\
\hline
\end{tabular}

Table 5 shows the frequency of the respondents based on race. Most of the trainee counselors responding were Malay- $82.8 \%(n=169)$, followed by Chinese $4.4 \%(n=9)$, and Indian $3.9 \%(n=8)$. Other races such as Murut, Kadazan, Bugis, Jawa, and Dusun totalled 8.8.\% ( $n=18)$. For the supervisor group, most of the respondents were Malay- $91.9 \% n=57)$, Chinese $3.2 \%(n=2)$, also Indian $1.6 \%(n=1)$ and other races constituted $3.2 \%(n=2)$.

Table 5: Frequency of trainee counselor and supervisor lecturer according to race

\begin{tabular}{|c|c|c|c|c|}
\hline Race & Trainee counselor & Percentage (\%) & Supervisor lecturer & Percentage (\%) \\
\hline Malay & 169 & 82.8 & 57 & 91.9 \\
\hline Chinese & 9 & 4.4 & 2 & 3.2 \\
\hline Indian & 8 & 3.9 & 1 & 1.6 \\
\hline Others & 18 & 8.8 & 2 & 3.2 \\
\hline Total & 204 & $100 \%$ & 62 & $100 \%$ \\
\hline
\end{tabular}

$H_{01}$ Testing

A pearson product-moment correlation coefficient was analyzed to assess the relationship between role conflict and counseling competency among trainee counselors in supervision. The analysis outcome reveals that there is a significant positive relationship between 
Vol. 8, No. 4, 2019, E-ISSN: 2226-6348 @ 2019 HRMARS

role conflict and counseling competency among trainee counselors $(r(204)=.170, p<.05)$. Thus, at a significant level $<.05, \mathrm{H}_{01}$ is successfully rejected. This finding explains that the higher the role conflict faced by a trainee counselor, the higher his or her counseling competency level, and vice versa. However, the strength of the relationship between role conflict and competency among the trainee counselors in this study is at weak level.

Table 6: Correlation between role conflict and counseling competency

\begin{tabular}{|c|c|c|}
\hline \multirow{2}{*}{ Role conflict } & Counseling competency $(r)$ & Sig. \\
\cline { 2 - 3 } & $.170^{*}$ & .015 \\
\hline
\end{tabular}

${ }^{* *} \mathrm{p}<.01, * \mathrm{p}<.05$ (2 tailed)

$H_{02}$ Testing

Next, the second Pearson product-moment correlation coefficient analysis was conducted to determine the relationship between role ambiguity and counseling competency among trainee counselors in supervision. There is a significant negative relationship between both variables $(r(204)=-.542, p<.05)$. Thus, at a significant level<.05, $\mathrm{H}_{\mathrm{o} 2}$ is successfully rejected. This finding also explains that the higher the role ambiguity experienced by a trainee counsellor, the lower level of counseling competency possessed by the trainee counsellor, and vice versa. Based on the finding, the strength of the relationship between role ambiguity and competency among the trainee counselors is at strong level.

Table 7: Correlation between role ambiguity and counseling competency

\begin{tabular}{|c|c|c|}
\hline \multirow{2}{*}{ Role ambiguity } & Counseling competency $(r)$ & Sig. \\
\cline { 2 - 3 } & $-.542^{* *}$ & .000 \\
\hline
\end{tabular}

$* * p<.01, * p<.05$ (2 tailed)

$H_{03}$ Testing

A multiple linear regression was carried out to investigate whether or not role conflict and role ambiguity could significantly predict trainee counselor's counseling competencies. The results of the regression indicated that the model explained $29.5 \%$ of the variance and that the model was a significant predictor of counseling competencies, $(F(2,201)=41.994, p<.000)$. Meanwhile, role ambiguity contributed significantly to the model $(\beta=-.434, p<.05)$, while role conflict did not $(\beta=-.046, p>.05)$. In sum, through the finding of this analysis, $\mathrm{H}_{\circ 3}$ is able to be rejected, in part. Thus, the study model that can be constructed is as follows:

$$
\hat{Y}=\beta_{0}+\beta_{1} X_{1}+\beta_{2} X_{2}
$$

Counseling competencies $=106.111+(-.434)$ (role ambiguity)

Model Summary

\begin{tabular}{|c|c|c|c|c|}
\hline Model & $\mathrm{R}$ & R Square & Adjusted R Square & Std. Error of the Estimate \\
\hline 1 & $.543^{\mathrm{a}}$ & .295 & .288 & 9.68754 \\
\hline
\end{tabular}

a. Predictors: (Constant), role conflict, role ambiguity

b. Dependent Variable: counseling competencies 
INTERNATIONAL JOURNAL OF ACADEMIC RESEARCH IN PROGRESSIVE EDUCATION AND DEVELOPMENT

Vol. 8, No. 4, 2019, E-ISSN: 2226-6348 @ 2019 HRMARS

ANOVA $^{\mathrm{a}}$

\begin{tabular}{|l|c|c|c|c|c|c|}
\hline \multicolumn{2}{|l|}{ Model } & Sum of Squares & df & Mean Square & $\mathrm{F}$ & Sig. \\
\hline \multirow{4}{*}{1} & Regression & 7882.078 & 2 & 3941.039 & 41.994 & \multirow{2}{*}{$.000^{\mathrm{b}}$} \\
\cline { 2 - 6 } & Residual & 18863.550 & 201 & 93.849 & & \\
\cline { 2 - 6 } & Total & 26745.627 & 203 & & & \\
\hline
\end{tabular}

a. Dependent Variable: counseling competencies

b. Predictors: (Constant), role conflict, role ambiguity

\begin{tabular}{|c|c|c|c|c|c|c|}
\hline \multicolumn{7}{|c|}{ Coefficients $^{a}$} \\
\hline & & \multicolumn{2}{|c|}{ Unstandardized Coefficients } & $\begin{array}{c}\text { Standardized } \\
\text { Coefficients }\end{array}$ & & \\
\hline \multicolumn{2}{|c|}{ Model } & B & Std. Error & Beta & $\mathrm{t}$ & Sig. \\
\hline \multirow[t]{3}{*}{1} & (Constant) & 106.111 & 4.388 & & 24.184 & .000 \\
\hline & Role ambiguity & -.434 & .050 & -.555 & -8.701 & .000 \\
\hline & Role conflict & -.046 & .085 & -.034 & -.536 & .593 \\
\hline
\end{tabular}

a. Dependent Variable: counseling competencies

\section{Research Findings}

This study examined the relationships between role difficulties and competencies of trainee counselors in a process of supervision. The findings reported that both of the role difficulties in a supervision process, consisting of role conflict and role ambiguity significantly correlated with the competencies of trainee counselors. These findings are supported by Olk and Friedlander (1992), where they stated that the role conflict and role ambiguity for the majority of trainees can cause anxiety and dissatisfaction with the supervision process as well as clinical work. Such concern and dissatisfaction can eventually distract the concentration of trainee counselors on the development of the competency in the supervision process. Generally, the role conflict and role ambiguity were identified as the elements that formed a supervisory relationship in the literature such as in Ellis \& Ladany (1997); Ahmed, Majid, Zin, Phulpoto, \& Umrani, (2016). In past literature review, a majority suggest that supervisory relationship was highly related to the trainee counselor's competencies. For instance, Loganbill et al., (1982) state that theorists have established the supervisory relationship as a main platform by which supervisors assist the development of the trainees. Next, Inman \& Ladany (2008) perceived positive supervisory relationships to be correlated to successful supervision. In a similar vein, Nelson \&Friedlander (2001) asserted that literature has consistently supported that the quality of the supervisory relationship is a buffering mechanism that can lead to positive outcomes in supervision. Citing Ronnestad \& Skovholt (1993), research shows that the supervisory relationship is a critical aspect in the profesional development of trainees. Since all these studies indicate that supervisory relationship was highly related to the trainee counselor's competencies, automatically these role conflict and role ambiguity have the same association. This ultimately makes the studies support the outcome of our present work.

With regard to the nature of role conflict, this finding is parallel with the finding from previous research by Nelson \& Friedlander (2001), indicating that some trainees who had a conflict experience is associated by power struggles between both parties, supervisor and 
trainees. Some trainees are older than their supervisors, or are more experienced, so with these circumstances, the trainees expected that they were treated fairly, like equals and they had expressed disappointment at being treated like a subordinate, or specifically like a student or employee. Furthermore, the role conflict also occurs when the expectation differs between supervisor and trainees. It was stressed by the authors that the relationship began to be harmful when the trainees deliberately had to behave in ways that made their supervisors comfortable, even when it threatened their self-confidence and sense of professionalism in the process. This finding is also supported by Friedlander, Kelller, Peca- Baker, \& Olk (1986); Galdeano, Ahmed, Fati, Rehan, \& Ahmed, (2019) with regard to the correlation between role conflict and competencies where they find that the high level of role conflict correlated with low level of satisfaction and weak performance among the trainee counselors. If unresolved, there is the possibility that the role conflict can be detrimental not only to the relationship between supervisor and trainee counselor, but also to the client's welfare.

In contrast, the role ambiguity's result is supported with previous study by Rønnestad \& Skovholt, (2012), in which for trainee counselors, they have to deal with the ambiguity of role, they have to learn new information and skills, work with clients for the first time, adapt to multiple sources of influence or information, develop self-empathy as individuals and professionals, and generally enhance their awareness of human complexity. Meanwhile, Olk \& Friedlander (1992) suggest that it is possible for novice counselors to become unsure regarding the personel issues are suitable to be discussed, the limitation of the information should be revealed, or the implications are for disagreeing with or criticizing a supervisor. However, the level of ambiguity is reduced as trainees obtain experience and confidence so the process of evaluation and behavioral expectations have become clear. Regarding the last finding, the role ambiguity found had a significant influence toward competencies of trainee counselor, while role conflict was not. This finding is consistent with the study by Olk \& Friedlander (1992), stated their results suggest that as counselors go through every training level, the role ambiguity is more prevalent than role conflict, but fortunately, issues with role ambiguity diminish as they become more and more experienced. As students, new trainees tend to accept supervisors' directives without question compared to interns or post-interns. As trainees gain experience, however, their approaches to and convictions about counseling crystallize, so there is a possibility that they might not want to follow some of their supervisors' suggestions. As found in this current work, the supervision process is still a learning curve for the trainees where possibly, they are still unclear about the role of an experienced and effective counselor. For this reason, the factor of role ambiguity is found to have a significant influence in this study.

\section{Conclusion}

This present study contributes to the supervision research specifically with respect to the competency and profesional development of trainee counselors. A search on previous literature did not bring us to many similar studies, especially with regard to trainee counselors in Malaysia. The study further clearly provides some empirical findings of the association between role conflict and role ambiguity with counseling competencies in the Malaysian context. Between both aspects, only role ambiguity had significantly influenced competencies of trainee counselors. The self-reported measure used for data collection in this study could be used to 
suggest supervisors as well as counselor educators to further develop and understand how far the role difficulties can affect the competencies of these new counselors. Conclusively, it can be said that the difficulties of trainee counselors to carry out their roles were inherent to the supervision process, and as such they may need help to encounter these issues in their learning. Based on the findings of this study, role difficulties should be tolerated in the supervision. It is recommended that future researchers are to investigate it as an alternative for trainee counselors to transform themselves into professional and competent counselors.

\section{Corresponding Author}

Name: $\quad$ Suhaili Arifin

Affiliation: Department of Counselor Education and Counseling Psychology, Faculty of Educational Studies, University of Putra Malaysia

Country: Malaysia.

E-mail ID: $\quad$ suhaili@ymail.com

Address: $\quad$ Lot 396, Jalan Surau Haji Yaakub, Kg. Tebauk, Bukit Tunggal, 21200 Kuala Nerus, Terengganu, Malaysia.

\section{References}

Ahmed, U., Majid, A. H., Zin, M. L., Phulpoto, W., \& Umrani, W. A. (2016). Role and impact of reward and accountability on training transfer. Business and Economics Journal, $7(1)$. http://dx.doi.org/10.4172/2151-6219.1000195

Babbie, E. R. (2014). The basic of social research. ( $6^{\text {th }}$ ed.). Belmont, CA: Wadsworth Cengage Learning.

Bernard, J. M., \& Goodyear, R. K. (2009). Fundamentals of clinical supervision (4th ed.). Upper Saddle River, NJ: Pearson.

Board of Counselor (Malaysia) (2011). Counselor Code of Ethics. Kuala Lumpur. Board of Counselor Publication.

Board of Counselor (Malaysia) (2015). Counselor Training Standard and Qualification. Putrajaya: Board of Counselor.

Bordens, K., \& Abott, B. B. (2014). Research design and methods: A Process approach. (9 $9^{\text {th }}$ ed.). New York, NY: McGraw -Hill.

Bornsheuer-Boswell, J. N., Polonyi, M. M., \& Watts, R. E. (2013). Integrating Alderian and integrated developmental model approaches to supervision of counseling trainees. The Journal of Individual Psychology, 66 (4), 328-343.

Brislin, R. W., Lonner, W. J. \& Thondike, R. M. (1973). Cross cultural research methods. New York: John Wiley \& Sons.

Creswell, J. W. (2012). Educational research: Planning, conducting and evaluating quantitative and qualitative research ( $4^{\text {th }}$ ed.). Boston: Pearson Education.

Dollarhide, C. T., \& Miller, G. M. (2006). Supervision for preparation and practice of school counsellors: Pathways to excellence. Counsellor supervision and education 45(4), 242-252.

Ellis, M. V., \& Ladany, N. (1997). Inferences concerning supervisees and clients in clinical supervision: An integrative review. In C. E. J. Watkins (Eds.), Handbook of psychotherapy supervision (pp. 447-507). Hoboken, NJ: John Wiley \& Sons. 
INTERNATIONAL JOURNAL OF ACADEMIC RESEARCH IN PROGRESSIVE EDUCATION AND DEVELOPMENT

Vol. 8, No. 4, 2019, E-ISSN: 2226-6348 @ 2019 HRMARS

Foster, V. A., \& McAdams, C. R., III. (2009). A framework for creating a climate of transparency for professional performance assessment: Fostering student investment in gatekeeping. Counselor Education and Supervision, 48(4), 271-284.

Friedlander, M. L., Keller, K. E., Peca-Baker, T. A., \& Olk, M. E. (1986). Effects of role conflict on counselor trainees' self-statements, anxiety level, and performance. Journal of Counseling Psychology, 31, 541-557.

Galdeano, D., Ahmed, U., Fati, M., Rehan, R., \& Ahmed, A. (2019). Financial performance and corporate social responsibility in the banking sector of Bahrain: Can engagement moderate? Management Science Letters, 9(10), 1529-1542.

Inman, A. G., \& Ladany, N. (2008). Research: The state of the field. Psychotherapy Supervision: Theory, Research, and Practice, 2, 500-517.

Jahn, S. A. B., \& Smith-Adcock, S. (2017). A phenomenological Study of Counseling Students' Experiences with Ambiguity. The Journal of Counselor Preparation and Supervision, 10 (1), 9. Retrieved April 29, 2019, from https://repository.wcsu.edu/jcps/vol10/iss1/9

Kulp, L. E. (2012). Supervision Factors that Predict Trainee Role Conflict and Role Ambiguity. (Doctoral Dissertation The Lehigh University) Digital Dissertation 1334.

Ladany, N., \& Bradley, L. J. (2010). Counselor supervision. (4 ${ }^{\text {th }}$ ed.). New York: Routledge..

Ladany, N., \& Malouf, M. A. (2010). Understanding and Conducting Supervision Research. In: Ladany, N., \& Bradley, L. J. (4 ${ }^{\text {th }}$ ed.), Counselor Supervision (pp. 353-388). New York, US: Routledge, Taylor \& Francis Group.

Lambie, G. W., Mullen, P. R., Swank, J. M., \& Blount, A. (2018) The Counseling Competencies Scale: Validation and Refinement, Measurement and Evaluation in Counseling and Development, 51(1), 1-15, DOI: 10.1080/07481756.2017.1358964

Loganbill, C., Hardy, E., \& Delworth, U. (1982). Supervision: A conceptual model. The Counselling Psychologist, 10(1), 3-41.

Nelson, M. L., \& Friedlander, M. L. (2001). A close look at conflictual supervisory relationships: The trainee's perspective. Journal of Counseling Psychology, 48(4), 384-395.

Olk, M., \& Friedlander, M. L. (1992). Role conflict and ambiguity in the supervisory experience of counselor trainees. Journal of Counseling Psychology, 39, 389-397.

Pelling, N. (2009). Counsellor competence - A survey of Australian Counsellor self perceived competence. The Professional Counsellor, 02, 1-8.

Ridley, C. R., Mollen, D., \& Kelly, S. M. (2011). Beyond microskills: Toward a model of counseling competence. The Counseling Psychologist, 1-40. DOI: 10.1177/0011000010378440.

Rønnestad, M. H. \& Skovholt, T. M. (1993). Supervision of beginning and advanced graduate students of counseling and psychotherapy. Journal of Counseling Development, 71, 396405.

Rønnestad, M. H. \& Skovholt, T. M. (2012). Developing Practitioner. New York, NY: Routledge.

Swank, J. M. (2014). Assessing counseling competencies: A comparison of supervisors' ratings and student supervisees' self-ratings. Counseling Outcome Research and Evaluation, 5(1), 17-27. DOI: $10.1177 / 2150137814529147$

West, W. (2004). Learning from a qualitative study into counseling supervision: listening to supervisor and supervisee. Counseling and Psychotherapy Research, 4(2), 20- 26. 